\title{
Pyrosequencing analysis of IRS1 methylation levels in schizophrenia with tardive dyskinesia
}

\author{
YANLI LI $^{1}$, KESHENG WANG ${ }^{2}$, PING ZHANG ${ }^{1}$, JUNCHAO HUANG $^{1}$, YING LIU $^{3}$, \\ ZHIREN WANG ${ }^{1}$, YONGKE LU ${ }^{4}$, SHUPING TAN ${ }^{1}$, FUDE YANG $^{1}$ and YUNLONG TAN ${ }^{1}$
}

${ }^{1}$ Beijing Huilongguan Hospital, Peking University Huilongguan Clinical Medical School, Beijing 100096, P.R. China;

${ }^{2}$ Department of Family and Community Health, School of Nursing, Health Sciences Center, West Virginia University, Morgantown, WV 26506; ${ }^{3}$ Department of Biostatistics and Epidemiology, College of Public Health, East Tennessee State University, Johnson City, TN 37614; ${ }^{4}$ Department of Biomedical Sciences, Joan C. Edwards School of Medicine, Marshall University, Huntington, WV 25755, USA

Received July 4, 2019; Accepted January 17, 2020

DOI: $10.3892 / \mathrm{mmr} .2020 .10984$

\begin{abstract}
Tardive dyskinesia (TD) is a serious side effect of certain antipsychotic medications that are used to treat schizophrenia (SCZ) and other mental illnesses. The methylation status of the insulin receptor substrate 1 (IRSI) gene is reportedly associated with SCZ; however, no study, to the best of the authors' knowledge, has focused on the quantitative DNA methylation levels of the IRSI gene using pyrosequencing in SCZ with or without TD. The present study aimed to quantify DNA methylation levels of $4 \mathrm{CpG}$ sites in the IRSI gene using a Chinese sample including SCZ patients with TD and without TD (NTD) and healthy controls (HCs). The general linear model (GLM) was used to detect DNA methylation levels among the 3 proposed groups (TD vs. NTD vs. HC). Mean DNA methylation levels of $4 \mathrm{CpG}$ sites demonstrated normal distribution. Pearson's correlation analysis did not reveal any significant correlations between the DNA methylation levels of the $4 \mathrm{CpG}$ sites and the severity of SCZ. GLM revealed significant differences between the 3 groups for $\mathrm{CpG}$ site 1 and the average of the $4 \mathrm{CpG}$ sites $(\mathrm{P}=0.0001$ and $\mathrm{P}=0.0126$, respectively). Furthermore, the TD, NTD and TD + NTD groups demonstrated lower methylation levels in $\mathrm{CpG}$ site 1 $(\mathrm{P}=0.0003, \mathrm{P}<0.0001$ and $\mathrm{P}<0.0001$, respectively) and the average of $4 \mathrm{CpG}$ sites $(\mathrm{P}=0.0176, \mathrm{P}=0.0063$ and $\mathrm{P}=0.003$,
\end{abstract}

Correspondence to: Dr Kesheng Wang, Department of Family and Community Health, School of Nursing, Health Sciences Center, West Virginia University, 1 Medical Center Drive, Morgantown, WV 26506, USA

E-mail: kesheng.wang@hsc.wvu.edu

Dr Yunlong Tan, Beijing Huilongguan Hospital, Peking University Huilongguan Clinical Medical School, Huilongguan Town, Changping, Beijing 100096, P.R. China

E-mail: yltan21@126.com

Key words: schizophrenia, tardive dyskinesia, insulin receptor substrate 1, DNA methylation, pyrosequencing, general linear model respectively) compared with the $\mathrm{HC}$ group. The results revealed that both NTD and TD patients had significantly decreased DNA methylation levels compared with healthy controls, which indicated a significant association between the DNA methylation levels of the IRSI gene with SCZ and TD.

\section{Introduction}

Schizophrenia (SCZ) has a strong genetic component with a heritability of up to $80 \%(1,2)$. Tardive dyskinesia (TD) is presented by repetitive and jerking movements in the face, neck and tongue and is considered to be a serious side effect associated with the use of specific antipsychotic medications that are used to treat $\mathrm{SCZ}$ and other mental illnesses. TD may demonstrate a comorbidity of $20-30 \%$ with SCZ $(3,4)$. Recent studies have reported that complex interactions of genetic, environmental and epigenetic factors play important roles in SCZ and TD (4-7). DNA methylation is an epigenetic mechanism that influences $\mathrm{CG}$ dinucleotides by adding a methyl group $\left(\mathrm{CH}_{3}\right)$ to them. Previously, several studies have reported the association between DNA methylation and SCZ (8-12) and $\operatorname{TD}(13,14)$.

Insulin resistance has reportedly been associated with atherosclerosis and type 2 diabetes (15). The insulin receptor substrate 1 (IRSI) gene is located at 2q36.3 (16-18) and it may be involved in the regulation of critical metabolic and signaling and secretion pathways (19-22). A genome wide association study in a French sample showed that one single nucleotide polymorphism (SNP) rs2943641, within $500 \mathrm{~kb}$ upstream of the IRSI gene, was associated with type 2 diabetes, insulin resistance and hyperinsulinemia (23). Furthermore, the IRSI gene DNA methylation was associated with high body mass index (BMI) scores and obesity $(24,25)$. However, there was no significant association between the methylation of the IRSI gene and type 2 diabetes (26). Gunnell et al (27) attempted to evaluate the SNP rs1801278 in the IRS1 gene with SCZ but could not identify any significant association. Recently, IRSI gene methylation has been found to be associated with SCZ $(9,28)$. Pyrosequencing provides a quantitative analysis of DNA methylation levels (29-31) and has been employed 
to detect DNA methylation levels of the IRS1 gene in type 2 diabetes (26) and human islets of type 2 diabetes (32).

A pilot study using methylated DNA immunoprecipitation coupled with next-generation sequencing (our unpublished data) revealed that the IRSI gene was hypomethylated in TD compared with SCZ groups. The present study aimed to quantify DNA methylation levels of the IRS1 gene via pyrosequencing to examine the association of the IRSI gene DNA methylation levels with SCZ or TD. The general linear model (GLM) was used to examine the differences in the DNA methylation levels among diagnostic groups.

\section{Materials and methods}

Participants. The present study recruited 10 SCZ patients with TD and 10 without TD (NTD) from the Beijing Huilongguan Hospital (China) between January 2016 and June 2017. SCZ was diagnosed using the Diagnostic and Statistical Manual of Mental Disorders version IV (DSM-IV) (33) and TD was confirmed by two well-trained psychiatrists with extensive clinical experiences, based on the criteria of Schooler and Kane (34). The $20 \mathrm{SCZ}$ patients were administered with one of the following: Risperidone, paliperidone or olanzapine. The TD patients were typically between 18 and 40 years of age and demonstrated an abnormal involuntary movement scale (AIMS) score that was $>3$ in at least one part or $>2$ in two or more parts (35). The same criteria were used for NTD patients with AIMS=0. The exclusion criteria included: Patients with severe physical or organic encephalopathy, drug or alcohol abuse history (except tobacco), pregnant or lactating women, patients administered with neurotrophic agents or free radical metabolism drugs within 12 weeks prior to participation, and other mental illnesses demonstrating a diagnosis of DSM-IV Axis I (14). The severity of TD symptoms was assessed using AIMS, with an inter-rater correlation coefficient (ICC) $>0.80$. The patients' psychotic symptoms were evaluated using the positive and negative syndrome scale (PANSS) (36), with an ICC $>0.85$, which was maintained for the PANSS total score after the scale training. A total of 10 healthy controls (HCs) matched for age, sex and education were subsequently recruited from the local community. Ethical approval was received from the Ethics Review Board of Beijing Huilongguan Hospital, China, and written informed consent was obtained from all participants or their guardians.

DNA extraction, bisulfite treatment and pyrosequencing. Fasting venous blood $(5 \mathrm{ml})$ from a forearm vein was obtained from each participant at 7:00 a.m. the next morning after the day of clinical assessment. DNA was extracted from the above blood samples using a standard genomic DNA sample kit (Illumina, Inc.), according to the manufacturer's protocol. DNA concentration and purity were detected by NanoDrop spectrophotometer (NanoDrop Technologies, Thermo Fisher Scientific, Inc.) and the integrity was tested using $1 \%$ agarose gel electrophoresis (14). Subsequently, $500 \mathrm{ng}$ of each sample was treated with bisulfite, by employing the Epitect Bisulfite Kit (Qiagen $\mathrm{GmbH}$ ), according to the manufacturer's protocol. Parts of the $\mathrm{CpG}$ islands in the promoter region within the IRS1 gene were amplified with the help of PCR assays. DNA fragments were typically amplified using the PyroMark PCR kit (Qiagen $\mathrm{GmbH}$ ), according to the manufacturer's protocol, from $2 \mu \mathrm{l}$ bisulfite-treated genomic DNA. Sample preparation and pyrosequencing reactions were subsequently carried out using the PyroMark Q96 ID (Qiagen $\mathrm{GmbH}$ ). The pyrosequencing assays were performed for all the study samples on both Pyro Mark Q24 MDx and PyroMarkQ96 ID, while using Pyro Mark Gold reagents (Qiagen $\mathrm{GmbH}$ ). The Pyro Mark Assay Design software version 2.0 (Qiagen $\mathrm{GmbH}$ ) was used to generate the primers for the IRSI, targeting four CpGs in the gene promoter (Table I). Percentage of each $\mathrm{CpG}$ site and the mean methylation percentage of the $4 \mathrm{CpGs}$ quantitatively revealed the methylation levels.

Statistical analysis. The $\chi^{2}$ test was used to detect gender differences among TD, NTD and HC groups. Pearson's correlation analysis was concurrently used to examine the correlations among methylation levels among the $4 \mathrm{CpG}$ sites, average level of the $4 \mathrm{CpG}$ sites and severity of SCZ. Differences among the continuous variables including age and education were evaluated by Fisher's F test in the GLM. Normality of DNA methylation levels was tested by the Shapiro-Wilk test. Differences of DNA methylation levels among the 3 groups, TD, NTD and $\mathrm{HC}$, for individual $\mathrm{CpG}$ sites and the mean of 4 CpGs were detected using GLM. All the analyses were performed using SAS version 9.4 software (SAS Institute, Inc.). The PROC POWER statement in SAS was used to compute power in the present study. $\mathrm{P}<0.05$ was considered to indicate a statistically significant difference.

\section{Results}

Demographics and clinical characteristics. The demographic factors in the TD, NTD and HC groups are presented in Table II. No statistical significances were observed in age $(\mathrm{P}=0.910)$, sex $(\mathrm{P}=1.00)$ and educational levels $(\mathrm{P}=0.832)$ among the 3 groups. There were no significant differences between TD and NTD groups in the disease duration and treatment, drug dose quantized using CPZ equivalents or drug types. Additionally, no significant difference was observed between TD and NTD groups in the PANSS total, positive, negative or general scores (Table III).

Normality test. The average DNA methylation levels of the 4 CpG sites followed normal distribution (Fig. 1) based on the Shapiro-Wilk test $(\mathrm{P}>0.150)$.

Correlation analyses. Table IV demonstrated that no significant correlations were found among the individual methylation levels of the $4 \mathrm{CpG}$ sites (all P-values >0.05); however, $\mathrm{CpG}$ sites 1 and 4 demonstrated a strong correlation to the mean value of the $4 \mathrm{CpG}$ sites $(\mathrm{P}<0.0001)$. Furthermore, there were no obvious correlations among $\mathrm{CpG}$ sites and the severity of SCZ measured by PANSS scores.

GLM analyses. The linear GLM revealed significant differences with regard to the $\mathrm{CpG}$ site 1 and the mean value of the $4 \mathrm{CpG}$ sites $(\mathrm{P}=0.0001$ and $\mathrm{P}=0.0126$, respectively; Table $\mathrm{V}$ and Fig. 2), among the 3 groups. Furthermore, the HC group demonstrated higher methylation levels in the $\mathrm{CpG}$ site 1 
Table I. Primer sequences used in the pyrosequencing analysis.

\begin{tabular}{llcc}
\hline Primer type & \multicolumn{1}{c}{ Primer sequence } & CpG Sites & Position 5'-3' \\
\hline Forward & 5'-AGTGGTTATAGAGTTTGATGTTTATTAGT-3' & 4 & $146-174$ \\
Reverse & 5'-CCTAAAACCCAAAAACCTAAATCA-3' & & $294-271$ \\
Sequencing & 5'-GTTTGATGTTTATTAGTTGTAGTA-3' & $158-181$ \\
\hline
\end{tabular}

Table II. Descriptive characteristics of patients and controls.

\begin{tabular}{lcccr}
\hline Variable & TD group $(\mathrm{n}=10)$ & NTD group $(\mathrm{n}=10)$ & HC group (n=10) & P-value \\
\hline Male/female & $5 / 5$ & $5 / 5$ & $5 / 5$ & 1.000 \\
Age (years) & $31.6 \pm 11.8$ & $33.8 \pm 11.0$ & $33.2 \pm 11.9$ & 0.910 \\
Education (years) & $10.6 \pm 3.2$ & $10.9 \pm 2.6$ & $11.4 \pm 3.3$ & 0.832 \\
Duration of disease (years) & $11.1 \pm 11.1$ & $10.2 \pm 9.2$ & $\mathrm{n} / \mathrm{a}$ & 1.000 \\
Duration of treatment (months) & $25.6 \pm 22.1$ & $24.5 \pm 26.1$ & $\mathrm{n} / \mathrm{a}$ & 0.570 \\
CPZ equivalents (mg) & $662.1 \pm 431.4$ & $498.4 \pm 275.4$ & $\mathrm{n} / \mathrm{a}$ & 0.474 \\
Drug type & 1 & & $\mathrm{n} / \mathrm{a}$ & 0.584 \\
1 typical antipsychotic & 6 & 0 & $\mathrm{n} / \mathrm{a}$ & \\
1 atypical antipsychotic & 3 & 3 & $\mathrm{n} / \mathrm{a}$ & \\
2 atypical antipsychotics & & 7 & & \\
\hline
\end{tabular}

TD, schizophrenia patients with tardive dyskinesia; NTD, schizophrenia patients without tardive dyskinesia; HC, healthy controls. P-values are based on $\chi^{2}$ test for categorical variable and generalized linear model for continuous variable.

Table III. Clinical parameters of TD and NTD groups.

\begin{tabular}{lccr}
\hline Variable & TD group $(\mathrm{n}=10)$ & NTD group $(\mathrm{n}=10)$ & P-value \\
\hline PANSS total score & $74.0 \pm 21.6$ & $73.4 \pm 9.7$ & 0.633 \\
PANSS & & & \\
Positive & $17.0 \pm 7.2$ & $18.7 \pm 4.6$ & 0.489 \\
Negative & $23.6 \pm 8.5$ & $18.4 \pm 6.2$ & 0.184 \\
General & $33.6 \pm 8.6$ & $35.2 \pm 7.0$ & 0.458 \\
Abnormal involuntary movement scale & $13.4 \pm 5.3$ & 0 & $<0.0001$
\end{tabular}

TD, schizophrenia patients with tardive dyskinesia; NTD, schizophrenia patients without tardive dyskinesia; PANSS, positive and negative syndrome scale. P-values are based on t-test.

compared with those in TD, NTD and TD + NTD $(\mathrm{P}=0.0003$, $\mathrm{P}<0.0001$ and $\mathrm{P}<0.0001$, respectively) and the average of $4 \mathrm{CpG}$ sites $(\mathrm{P}=0.0176, \mathrm{P}=0.0063$ and $\mathrm{P}=0.003$, respectively).

\section{Discussion}

To the best of our knowledge, this is the first study to quantitatively analyze DNA methylation using pyrosequencing and determine the IRSI gene promoter methylation levels of the 4 CpG sites among the TD, NTD and HC groups. GLM analyses revealed lower methylation levels in $\mathrm{CpG}$ site 1 and the mean value of the $4 \mathrm{CpG}$ sites of the TD, NTD and TD + NTD groups compared with the control group.
The methylation status of the IRS1 gene has been found to be associated with SCZ through post-mortem analysis of human brain tissue from 24 patients with SCZ and 24 unaffected controls using the Illumina Infinium HumanMethylation450 Bead Chip (9). Another study using blood samples and Illumina HumanMethylation450 BeadChip reported that IRSI was associated with SCZ (28). The present study used pyrosequencing to reveal that the DNA methylation level in SCZ patients (NTD group) was significantly lower compared with healthy controls with regard to the $\mathrm{CpG}$ site 1 and average values of the $4 \mathrm{CpG}$ sites in a Chinese sample (Table V). Furthermore, it was observed that the TD group demonstrated significantly lower 
Table IV. Pearson correlation coefficients among methylation levels and clinical characters.

\begin{tabular}{|c|c|c|c|c|c|c|c|c|c|}
\hline Variable & $\begin{array}{l}\text { IRS1 } \\
\text { Site } 1\end{array}$ & $\begin{array}{l}\text { IRS1 } \\
\text { Site } 2\end{array}$ & $\begin{array}{l}\text { IRS1 } \\
\text { Site } 3\end{array}$ & $\begin{array}{l}\text { IRS1 } \\
\text { Site } 4\end{array}$ & $\begin{array}{c}\text { IRS1 } \\
\text { Average }\end{array}$ & PANSST & PANSSP & PANSSN & PANSSG \\
\hline IRS1 Site 1 & 1.000 & -0.345 & 0.299 & 0.285 & $0.821^{\mathrm{a}}$ & -0.323 & -0.499 & -0.219 & -0.121 \\
\hline IRS1 Site 2 & & 1.000 & -0.055 & -0.222 & -0.276 & -0.092 & 0.013 & 0.122 & 0.037 \\
\hline IRS1 Site 3 & & & 1.000 & 0.076 & 0.310 & 0.198 & 0.013 & 0.266 & 0.111 \\
\hline IRS1 Site 4 & & & & 1.000 & $0.770^{\mathrm{a}}$ & 0.059 & -0.052 & -0.051 & 0.153 \\
\hline IRS1 Average & & & & & 1.000 & -0.160 & -0.366 & -0.128 & 0.008 \\
\hline PANSST & & & & & & 1.000 & $0.521^{\mathrm{b}}$ & $0.832^{\mathrm{a}}$ & $0.836^{\mathrm{a}}$ \\
\hline PANSSP & & & & & & & 1.000 & 0.184 & 0.177 \\
\hline PANSSN & & & & & & & & 1.000 & $0.623^{c}$ \\
\hline PANSSG & & & & & & & & & 1.000 \\
\hline
\end{tabular}

${ }^{\mathrm{a}} \mathrm{P}<0.0001,{ }^{\mathrm{b}} \mathrm{P}<0.05,{ }^{\mathrm{c}} \mathrm{P}<0.01$. IRS1, insulin receptor substrate 1 ; PANSS, positive and negative syndrome scale; PANSST, the total score; PANSSP, positive score; PANSN, negative score; PANSSG, general psychopathology score.

Table V. General linear model analysis of DNA methylation levels.

\begin{tabular}{|c|c|c|c|c|c|c|}
\hline Group & Mean/F/t/P-value & Site 1 & Site 2 & Site 3 & Site 4 & Average \\
\hline $\mathrm{TD}$ & Mean \pm standard deviation & $84.3 \pm 3.8$ & $100.0 \pm 0.0$ & $100.0 \pm 0.0$ & $86.9 \pm 1.3$ & $92.8 \pm 1.0$ \\
\hline NTD & & $84.0 \pm 3.4$ & $99.7 \pm 0.7$ & $99.8 \pm 0.7$ & $86.8 \pm 2.9$ & $92.6 \pm 1.4$ \\
\hline $\mathrm{HC}$ & & $90.2 \pm 1.4$ & $99.8 \pm 0.7$ & $100.0 \pm 0.0$ & $87.8 \pm 5.6$ & $94.4 \pm 1.6$ \\
\hline \multirow[t]{2}{*}{ TD vs. NTD vs HC } & F value & 13.14 & 0.51 & 0.95 & 0.14 & 5.20 \\
\hline & $\mathrm{P}$-value & 0.0001 & 0.6052 & 0.4011 & 0.8659 & 0.0126 \\
\hline \multirow[t]{2}{*}{ TD vs. HC } & t value & -4.22 & 0.92 & 0.0 & -0.42 & -2.53 \\
\hline & P-value & 0.0003 & 0.3677 & 1.0000 & 0.6758 & 0.0176 \\
\hline \multirow[t]{2}{*}{ NTD vs. HC } & $\mathrm{t}$ value & -4.59 & 0.07 & -1.20 & 0.06 & -2.97 \\
\hline & P-value & $<0.0001$ & 0.9433 & 0.2403 & 0.9524 & 0.0063 \\
\hline \multirow[t]{2}{*}{ TD + NTD vs. HC } & $\mathrm{t}$ value & -5.21 & 0.56 & -0.72 & -0.54 & -3.26 \\
\hline & P-value & $<0.0001$ & 0.5822 & 0.4762 & 0.5903 & 0.0030 \\
\hline \multirow[t]{2}{*}{ TD vs. NTD } & t value & 0.25 & 0.85 & 1.17 & -0.50 & 0.36 \\
\hline & P-value & 0.8072 & 0.4048 & 0.2527 & 0.6237 & 0.7220 \\
\hline
\end{tabular}

TD, schizophrenia patients with tardive dyskinesia; NTD, schizophrenia patients without tardive dyskinesia; HC, healthy controls. F value is based on GLM for comparing three groups and t value is based on GLM for comparing two groups.

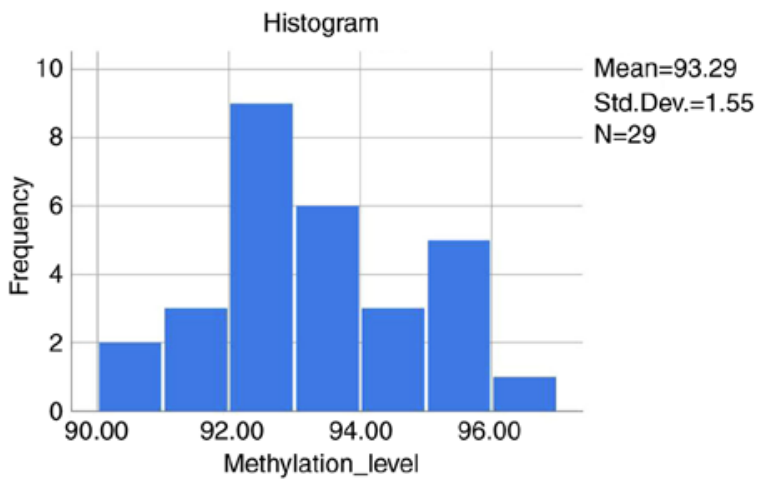

Figure 1. Normality test for the average methylation level for $4 \mathrm{CpG}$ sites.

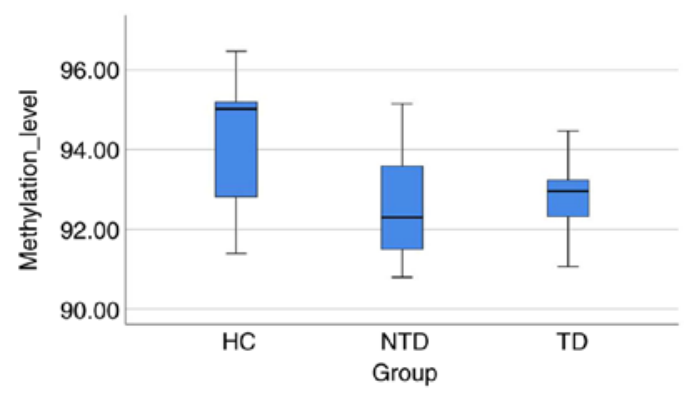

Figure 2. F-test based on GLM analysis of the average methylation levels of $4 \mathrm{CpG}$ sites for comparing three groups. HC, healthy controls; NTD, schizophrenia patients without tardive dyskinesia; TD, schizophrenia patients with tardive dyskinesia.
DNA methylation levels compared with healthy controls (Table V).
Studies have previously indicated that insulin may act as a metabolic signal and the IRS1 gene may influence body 
weight control and glucose homeostasis (37-39). Furthermore, several studies have also reported associations of IRSI polymorphisms with cancer, diabetes, glucose levels and obesity (40-44). Furthermore, insulin/insulin receptor signaling and the insulin-like growth factor (IGF) pathway may have different functions in the central nervous system in brain development, blood glucose regulation, dendritic growth and neuronal apoptosis (37,45-48). However, Che et al (47) was unable to identify any association between the IRSI gene and epilepsy in a Chinese sample but suggested that the genes associated with the insulin signaling pathway may affect the therapeutic response of temporal lobe epilepsy. Previous epidemiologic studies have demonstrated that SCZ and other mental illnesses may increase the risk of developing type 2 diabetes and other metabolic disorders $(49,50)$. The co-morbidity of type 2 diabetes and SCZ may partially be due to concurrent biological susceptibility of these two conditions $(51,52)$. As an example, the TCF7L2 gene is associated with both type 2 diabetes and type 2 diabetes with SCZ or the schizoaffective disorder observed in African American patients (50), while the rs7903146 in the TCF7L2 gene is associated with SCZ (53). Furthermore, insulin-like growth factor II mRNA-binding protein 2 gene (IGF2BP2) may be associated with SCZ (54). Additionally, insulin signaling, among other type 2 diabetes-related pathways, could act as a bridge between SCZ and type 2 diabetes (55). However, one previous study could not associate rs 1801278 in the IRS1 gene with SCZ (27). Therefore, the present study provided further evidence of the involvement of IRSI gene with regard to the development of SCZ or TD (Table IV).

A previous study examined the DNA methylation levels of three $\mathrm{CpG}$ sites in the IRS1 gene with type 2 diabetes using pyrosequencing (26); however, there was no significant difference in the methylation levels of the $3 \mathrm{CpG}$ sites in the IRSI gene between the controls and type 2 diabetes patients, which suggested that the DNA methylation levels of the IRSI gene did not play a major role in the occurrence of type 2 diabetes (26). The present study revealed that both TD and NTD groups had significantly lower methylation levels in the $\mathrm{CpG}$ site 1 and mean values of the $4 \mathrm{CpG}$ sites in the IRSI gene compared with healthy controls (Table V). One primary difference may be that there were $3 \mathrm{CpG}$ sites in the above type 2 diabetes study (26), while there were 4 in the present study; however, it is possible that these $\mathrm{CpG}$ sites may be different. Notably, the present study found numerous similarities, which included the fact that DNA methylation levels in the diabetes groups were slightly lower compared with those in the non-diabetes groups, specifically in the $\mathrm{CpG}$ sites 1 and 2 in the entire sample. Furthermore, in the above type 2 diabetes study, a similar trend was noted among the groups of men and women, despite the fact that the differences did not reach a 5\% significant level (26).

Previous studies have suggested a role of IRS1 in cognitive impairment and Alzheimer's disease (56-59). The present study and the previous reports related to the role of IRSI gene methylation in $\operatorname{SCZ}(9,28)$ may provide adequate evidence to demonstrate that SCZ and Alzheimer's disease may share a common network of dysregulation (60). Furthermore, epidemiologic studies have reported a possible association between the insulin resistance of type 2 diabetes mellitus and increased incidence of Alzheimer's disease $(61,62)$. As a matter of fact, insulin resistance results in a diminished glucose uptake in similar regions of the brain in Alzheimer's disease and type 2 diabetes mellitus $(58,59)$. Therefore, the IRS1 gene may have a pleiotropic effect on Alzheimer's disease, type 2 diabetes and SCZ.

There are a number of strengths in the current study. First, this is the first study to conduct a quantitative analysis of DNA methylation levels of the IRS1 gene in SCZ and TD, while previous studies focused on the methylation status in SCZ $(9,28)$. Second, the present study applied a GLM to examine the methylation levels of the $4 \mathrm{CpG}$ sites within the IRS1 gene among TD, NTD and HC groups. Third, the present study tested the normality of the average methylation levels of the $4 \mathrm{CpG}$ sites and observed that the average DNA methylation levels of these sites followed normal distribution. Although correlation analysis was performed, significant correlations among the methylation percentages of the four $\mathrm{CpG}$ sites with the severity of $\mathrm{SCZ}$ was not observed. However, the present study has certain limitations: First, a peripheral blood sample was used in view of the difficulty in obtaining brain tissues to study the disorders of the central nervous system. Second, the sample size of the three groups in the methylation study was relatively small because the prevalence of TD in general population is typically low. Based on the PROC POWER determined in SAS 9.4, the power level was $63.3 \%$ with 30 individuals on comparing overall means in DNA methylation levels for the four $\mathrm{CpG}$ sites; however, it was possible to increase the power up to 99.1\% while testing the $\mathrm{CpG}$ site 1 . Third, the present study examined and included a limited number of sites associated with IRSI gene methylation (only 4 sites), which highlighted the importance of increasing the number of sites in future investigations. Additionally, there may be variations between medications, which could not have been detected by the present study.

In conclusion, pyrosequencing demonstrated that the DNA methylation levels of the IRSI gene in TD and NTD groups were significantly lower compared with the healthy control group. However, the DNA methylation levels in TD did not demonstrate any significant differences compared with those in the NTD group. This is the first study to compare $\mathrm{CpG}$ methylation levels of TD and NTD with healthy controls and the findings demonstrated adequate evidence of the possible roles of IRS1-associated DNA methylation in SCZ and TD. In the future, it will be worthy to detect age and gender effects using a large sample and perform the functional study of these $4 \mathrm{CpG}$ sites of the IRS1 gene to evaluate the role of this gene in the pathogenesis of SCZ and TD.

\section{Acknowledgements}

The authors would like to thank KangChen Bio-Tech Co., Ltd. for experimental assistance in MeDIP sequencing and Beijing Liuhe Huada Gene Technology Co., Ltd. for experiment assistance in pyrosequencing.

\section{Funding}

Dr Yunlong Tan received support from the Beijing Natural Science Foundation (grant no. 7151005) and the National 
Science Foundation of China (grant no. 81771452) for the present study.

\section{Availability of data and materials}

The datasets used and/or analyzed during the current study are available from the corresponding authors on reasonable request.

\section{Authors' contributions}

YLL, FY and YT planned and managed the project. YLL, $\mathrm{JH}, \mathrm{ZW}, \mathrm{FY}$ and ST were involved in designing the study and collecting the data. YLL, PZ, ZW and ST performed recruitment and clinical assessment. KW, PZ, YLL, YL, YKL and YT conducted statistical analyses, interpreted the results, searched the literatures and wrote parts of the manuscript. All authors performed a final review of the manuscript and all authors approved the submission of this manuscript.

\section{Ethics approval and consent to participate}

The current study was approved by the Ethics Review Board of Beijing Huilongguan Hospital (China). Written informed consent was obtained from all participants enrolled in our study and/or from their guardians.

\section{Patient consent for publication}

Not applicable.

\section{Competing interests}

The authors declare that they have no competing interests.

\section{References}

1. Sullivan PF, Kendler KS and Neale MC: Schizophrenia as a complex trait: Evidence from a meta-analysis of twin studies. Arch General Psychia 60: 1187-1192, 2003.

2. Gejman PV, Sanders AR and Duan J: The role of genetics in the etiology of schizophrenia. Psychiatr. Clin North Am 33: 35-66, 2010.

3. Tarsy D, Lungu C and Baldessarini RJ: Epidemiology of tardive dyskinesia before and during the era of modern antipsychotic drugs. J Handb Clin Neurol 100: 601-616, 2011.

4. Correll CU, Kane JM and Citrome LL: Epidemiology, prevention, and assessment of tardive dyskinesia and advances in treatment. J Clin Psychiatry 78: 1136-1147, 2017.

5. Csoka AB and Szyf M: Epigenetic side-effects of common pharmaceuticals: A potential new field in medicine and pharmacology. Med Hypotheses 73: 770-780, 2009.

6. Lee HJ and Kang SG: Genetics of tardive dyskinesia. Int Rev Neurobiol 98: 231-264, 2011.

7. Lanning RK, Zai CC and Müller DJ: Pharmacogenetics of tardive dyskinesia: An updated review of the literature. Pharmacogenomics 17: 1339-1351, 2016.

8. Nishioka M, Bundo M, Kasai K and Iwamoto K: DNA methylation in schizophrenia: Progress and challenges of epigenetic studies. Genome Med 4: 96, 2012.

9. Wockner LF, Noble EP, Lawford BR, Young RM, Morris CP, Whitehall VL and Voisey J: Genome-wide DNA methylation analysis of human brain tissue from schizophrenia patients. Transl Psychiatry 4: e339, 2014.

10. Hannon E, Dempster E, Viana J, Burrage J, Smith AR, Macdonald R, St Clair D, Mustard C, Breen G, Therman S, et al: An integrated genetic-epigenetic analysis of schizophrenia: Evidence for co-localization of genetic associations and differential DNA methylation. Genome Biol 17: 176, 2016.
11. Lee SA and Huang KC: Epigenetic profiling of human brain differential DNA methylation networks in schizophrenia. BMC Med Genomics 9 (Suppl 3): S68, 2016.

12. Pries LK, Gülöksüz S and Kenis G: DNA Methylation in Schizophrenia. Adv Exp Med Biol 978: 211-236, 2017.

13. Zhang P, Li YL, An HM and Tan YL: Preliminary construction of DNA methylation profiles of schizophrenia patients with tardive dyskinesia. Chin J Psychiatry 51: 13-19, 2018.

14. Li Y, Wang KS, Zhang P, Huang J, An H, Wang N, Yang F, Wang Z, Tan S, Chen S and Tan YL: Quantitative DNA methylation analysis of DLGAP2 gene using pyrosequencing in schizophrenia with tardive dyskinesia: A linear mixed model approach. Sci Rep 8: 17466, 2018.

15. Abe H, Yamada N, Kamata K, Kuwaki T, Shimada M, Osuga J, Shionoiri F, Yahagi N, Kadowaki T, Tamemoto H, et al: Hypertension, hypertriglyceridemia, and impaired endothelium-dependent vascular relaxation in mice lacking insulin receptor substrate-1. J Clin Invest 101: 1784-1788, 1998.

16. Sun XJ, Rothenberg P, Kahn CR, Backer JM, Araki E, Wilden PA, Cahill DA, Goldstein BJ and White MF: Structure of the insulin receptor substrate IRS-1 defines a unique signal transduction protein. Nature 352: 73-77, 1991.

17. Stoffel M, Espinosa R III, Keller SR, Lienhard GE, Le Beau MM and Bell GI: Human insulin receptor substrate-1 gene (IRS1): Chromosomal localization to 2q35-q36.1 and identification of a simple tandem repeat DNA polymorphism. Diabetologia 36: 335-337, 1993.

18. Nishiyama M, Inazawa J, Ariyama T, Nakamura Y, Matsufuji S, Furusaka A, Tanaka T, Hayashi S and Wands JR: The human insulin receptor substrate-1 gene (IRS1) is localized on 2 q36. Genomics 20: 139-141, 1994.

19. Myers MG Jr, Sun XJ and White MF: The IRS-1 signaling system. Trends Biochem Sci 19: 289-293, 1994.

20. Kulkarni RN, Winnay JN, Daniels M, Brüning JC, Flier SN, Hanahan D and Kahn CR: Altered function of insulin receptor substrate-1-deficient mouse islets and cultured beta-cell lines. J Clin Invest 104: R69-R75, 1999.

21. Kido Y, Burks DJ, Withers D, Bruning JC, Kahn CR, White MF and Accili D: Tissue-specific insulin resistance in mice with mutations in the insulin receptor, IRS-1, and IRS-2. J Clin Invest 105: 199-205, 2000.

22. Kim JK, Fillmore JJ, Sunshine MJ, Albrecht B, Higashimori T, Kim DW, Liu ZX, Soos TJ, Cline GW, O'Brien WR, et al: PKC-theta knockout mice are protected from fat-induced insulin resistance. J Clin Invest 114: 823-827, 2004.

23. Rung J, Cauchi S, Albrechtsen A, Shen L, Rocheleau G, Cavalcanti-Proença C, Bacot F, Balkau B, Belisle A, Borch-Johnsen K, et al: Genetic variant near IRS1 is associated with type 2 diabetes, insulin resistance and hyperinsulinemia. Nat Genet 41: 1110-1115, 2009.

24. Rönn T, Volkov P, Gillberg L, Kokosar M, Perfilyev A, Jacobsen AL, Jørgensen SW, Brøns C, Jansson PA, Eriksson KF, et al: Impact of age, BMI and HbA1c levels on the genome-wide DNA methylation and mRNA expression patterns in human adipose tissue and identification of epigenetic biomarkers in blood. Hum Mol Genet 24: 3792-3813, 2015.

25. Fradin D, Boëlle PY, Belot MP, Lachaux F, Tost J, Besse C, Deleuze JF, De Filippo G and Bougnères P: Genome-wide methylation analysis identifies specific epigenetic marks in severely obese children. Sci Rep 7: 46311, 2017.

26. Ma J, Cheng J, Wang L, Wang H, Xu L, Liu P, Bu S, Zhang L, Le Y, Ye M, et al: No association between IRS-1 promoter methylation and type 2 diabetes. Mol Med Rep 8: 949-953, 2013.

27. Gunnell D, Lewis S, Wilkinson J, Georgieva L, Davey GS, Day IN, Holly JM, O'Donovan MC, Owen MJ, Kirov G and Zammit S: IGF1, growth pathway polymorphisms and schizophrenia: A pooling study. Am J Med Genet B Neuropsychiatr Genet 144B: 117-120, 2007.

28. Montano C, Taub MA, Jaffe A, Briem E, Feinberg JI, Trygvadottir R, Idrizi A, Runarsson A, Berndsen B, Gur RC, et al: Association of DNA methylation differences with schizophrenia in an epigenome-wide association study. JAMA Psychiatry 73: 506-514, 2016.

29. Tost J and Gut IG: DNA methylation analysis by pyrosequencing. Nat Protoc 2: 2265-2275, 2007.

30. Mikeska T, Felsberg J, Hewitt CA and Dobrovic A: Analysing DNA methylation using bisulphite pyrosequencing. Methods Mol Biol 791: 33-35, 2011.

31. Fakruddin $\mathrm{M}$ and Chowdhury A: Pyrosequencing-An alternative to traditional Sanger sequencing. Am J Biochem Biotech 8: 14-20, 2012. 
32. Dayeh TA, Olsson AH, Volkov P, Almgren P, Rönn T and Ling C: Identification of CpG-SNPs associated with type 2 diabetes and differential DNA methylation in human pancreatic islets. Diabetologia 56: 1036-1046, 2013.

33. American Psychiatric Association. Diagnostic and Statistical Manual of Mental Disorders (DSM-IV). Washington, DC: American Psychiatric Association, 1994.

34. Schooler NR and Kane JM: Research diagnoses for tardive dyskinesia. Arch Gen Psychiatry 39: 486-487, 1982.

35. Fan B: Abnormal involuntary movement rating scale (AIMS). Shanghai Arch Psychiat: 80-81, 1984.

36. Kay SR, Fiszbein A and Opler LA: The positive and negative syndrome scale (PANSS) for schizophrenia. Schizophr Bull 13: 261-276, 1987

37. White MF: Insulin signaling in health and disease. Science 302 : 1710-1711, 2003

38. Burks DJ, White MF. IRS proteins and $\beta$-cell function. Diabetes 50: 140-145, 2001.

39. Withers DJ, Burks DJ, Towery HH, Altamuro SL, Flint CL and White MF: IRS-2 coordinates IGF-1 receptor-mediated beta-cell development and peripheral insulin signalling. Nat Genet 23 : 32-40, 1999.

40. Lautier C, El Mkadem SA, Renard E, Brun JF, Gris JC, Bringer J and Grigorescu F: Complex haplotypes of IRS2 gene are associated with severe obesity and reveal heterogeneity in the effect of Gly1057Asp mutation. Hum Genet 113: 34-43, 2003.

41. Slattery ML, Samowitz W, Curtin K, Ma KN, Hoffman M, Caan B and Neuhausen S: Associations among IRS1, IRS2, IGF1, and IGFBP3 genetic polymorphisms and colorectal cancer. Cancer Epidemiol Biomark Prev 13: 1206-1214, 2004.

42. Neuhausen SL, Brummel S, Ding YC, Singer CF, Pfeiler G, Lynch HT, Nathanson KL, Rebbeck TR, Garber JE, Couch F, et al: Genetic variation in insulin-like growth factor signaling genes and breast cancer risk among BRCA1 and BRCA2 carriers. Breast Cancer Res 11: R76, 2009.

43. Feng X, Tucker KL, Parnell LD, Shen J, Lee YC, Ordovas JM, Ling WH and Lai CQ: Insulin receptor substrate 1 (IRS1) variants confer risk of diabetes in the Boston Puerto Rican Health Study. Asia Pac J Clin Nutr 22: 150-159, 2013.

44. Winder T, Giamas G, Wilson PM, Zhang W, Yang D, Bohanes P, Ning Y, Gerger A, Stebbing J and Lenz HJ: Insulin-like growth factor receptor polymorphism defines clinical outcome in estrogen receptor-positive breast cancer patients treated with tamoxifen. Pharmacogen J 14: 28-34, 2014.

45. Jones JI and Clemmons DR: Insulin-like growth factors and their binding proteins: Biological actions. Endocr Rev 16: 3-34, 1995.

46. Laban C, Bustin SA and Jenkins PJ: The GH-IGF-I axis and breast cancer. Trends Endocrinol Metab 14: 28-34, 2003.

47. Che F, Fu Q, Li X, Gao N, Qi F, Sun Z, Du Y and Li M Association of insulin receptor $\mathrm{H} 1085 \mathrm{H} \mathrm{C}>\mathrm{T}$, insulin receptor substrate 1 G972R and insulin receptor substrate $21057 \mathrm{G} / \mathrm{A}$ polymorphisms with refractory temporal lobe epilepsy in Han Chinese. Seizure 25: 178-180, 2015.

48. Park HJ, Kim SK, Kang WS, Park JK, Kim YJ, Nam M, Kim JW and Chung JH: Association between IRS1 gene polymorphism and autism spectrum disorder: A pilot case-control study in Korean males. Int J Mol Sci 17: E1227, 2016.

49. Suvisaari J, Perälä J, Saarni SI, Härkänen T, Pirkola S, Joukamaa M, Koskinen S, Lönnqvist J and Reunanen A: Type 2 diabetes among persons with schizophrenia and other psychotic disorders in a general population survey. Eur Arch Psychiatry Clin Neurosci 258: 129-136, 2008
50. Irvin MR, Wiener HW, Perry RP, Savage RM and Go RC: Genetic risk factors for type 2 diabetes with pharmacologic intervention in African-American patients with schizophrenia or schizoaffective disorder. Schizophr Res 114: 50-56, 2009.

51. Bellivier F: Schizophrenia, antipsychotics and diabetes: Genetic aspects. Eur Psychiatry 20 (Suppl 4): S335-S339, 2005.

52. Lin PI and Shuldiner AR: Rethinking the genetic basis for comorbidity of schizophreniaand type 2 diabetes. Schizophr Res 123: 234-243, 2010.

53. Hansen T, Ingason A, Djurovic $\mathrm{S}$, Melle I, Fenger M, Gustafsson $\mathrm{O}$, Jakobsen KD, Rasmussen HB, Tosato S, Rietschel M, et al: At-risk variant in TCF7L2 for type II diabetes increases risk of schizophrenia. Biol Psychiatry 70: 59-63, 2011.

54. Zhang X, Hui L, Liu Y, Wang ZQ, You Y, Miao LN, Sun SL, Guan SL, Xiang Y, Kosten TR and Zhang XY: The type 2 diabetes mellitus susceptibility gene IGF2BP2 is associated with schizophrenia in a Han Chinese population. J Clin Psychiatry 74: e287-e292, 2013.

55. Liu Y, Li Z, Zhang M, Deng Y, Yi Z and Shi T: Exploring the pathogenetic association between schizophreniaand type 2 diabetes mellitus diseases based on pathway analysis. BMC Med Genomics 6 (Suppl 1): S17, 2013.

56. Talbot K, Wang HY, Kazi H, Han LY, Bakshi KP, Stucky A, Fuino RL, Kawaguchi KR, Samoyedny AJ, Wilson RS, et al: Demonstrated brain insulin resistance in Alzheimer's disease patients is associated with IGF-1 resistance, IRS-1 dysregulation, and cognitive decline. J Clin Invest 122: 1316-1338, 2012.

57. Yarchoan M, Toledo JB, Lee EB, Arvanitakis Z, Kazi H, Han LY, Louneva N, Lee VM, Kim SF, Trojanowski JQ and Arnold SE: Abnormal serine phosphorylation of insulin receptor substrate 1 is associated with tau pathology in Alzheimer's disease and tauopathies. Acta Neuropathol 128: 679-689, 2014.

58. Kapogiannis D, Boxer A, Schwartz JB, Abner EL, Biragyn A, Masharani U, Frassetto L, Petersen RC, Miller BL and Goetzl EJ: Dysfunctionally phosphorylated type 1 insulin receptor substrate in neural-derived blood exosomes of preclinical Alzheimer's disease. FASEB J 29: 589-596, 2015.

59. Tanokashira D, Fukuokaya W and Taguchi A: Involvement of insulin receptor substrates in cognitive impairment and Alzheimer's disease. Neural Regen Res 14: 1330-1334, 2019.

60. Douaud G, Groves AR, Tamnes CK, Westlye LT, Duff EP, Engvig A, Walhovd KB, James A, Gass A, Monsch AU, et al: A common brain network links development, aging, and vulnerability to disease. Proc Natl Acad Sci USA 111: 17648-17653, 2014.

61. Schrijvers EM, Witteman JC, Sijbrands EJ, Hofman A, Koudstaal PJ and Breteler MM: Insulin metabolism and the risk of Alzheimer disease: The Rotterdam Study. Neurology 75: 1982-1987, 2010.

62. Qiu C, Sigurdsson S, Zhang Q, Jonsdottir MK, Kjartansson O, Eiriksdottir G, Garcia ME, Harris TB, van Buchem MA, et al: Diabetes, markers of brain pathology and cognitive function: The Age, Gene/Environment Susceptibility-Reykjavik Study. Ann Neurol 75: 138-146, 2014.

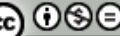

This work is licensed under a Creative Commons Attribution-NonCommercial-NoDerivatives 4.0 International (CC BY-NC-ND 4.0) License. 